\title{
Limacus flavus yellow slug: bioactive molecules in the mucus
}

\author{
Patricia Yumi Hayashida ${ }^{1,2}$ \& Pedro Ismael da Silva Júnior ${ }^{* 1,2}$ \\ ${ }^{1}$ Laboratory for Applied Toxinology (LETA) - Center of Toxins, Immune-Response and Cell \\ Signaling - CeTICS/CEPID, Butantan Institute, São Paulo, Brazil; ${ }^{2}$ Post-Graduation Program \\ Interunits in Biotechnology, USP/IPT/IBU, São Paulo, Brazil
}

\begin{abstract}
Background: Snails and slugs were used as a treatment for many health problems therefore ancient times. Since the antimicrobial resistance became a major global thread, antimicrobial peptides have been considered as a potential source for development of new drugs, especially for drug-resistant bacteria. Nowadays reports confirm that the mucous secretions have antimicrobial, antiviral and antifungal properties.
\end{abstract}

Methods: The present study has the objective to characterize and evaluate antimicrobial peptides of Limacus flavus mucus. The mucus was obtained by thermal shock and submitted to RP-HPLC. Fractions were used to perform the antimicrobial activity and hemolytic assays, electrophoresis (SDS-Page Gel) and submitted to mass spectrometry (LC-MS / MS). Identification and characterization was performed by PeaksX + software. The physicochemical parameters were evaluated with bioinformatics tools, which predicted water solubility, iso-electric point, charge net and its primary structure.

Results: Three fractions were isolated from the mucus of L. flavus and presented antifungal and antibacterial activity. The mucus showed greater inhibition for filamentous fungi (Aspergillus niger), yeast (Cryptococcus neoformans), Gram positive bacteria (Bacillus subtilis, Micrococcus luteus) and Gram negative bacteria (Enterobacter cloacae). These fractions also did not show hemolytic activity for human blood cells (erythrocytes). Fraction's sequences were identified and presents $\mathrm{Mw}<3 \mathrm{kDa}$, WLGH, DLQW, YLRW, respectively.

Conclusion: This study revealed three antimicrobial peptides of L. flavus mucus with a wide range of antimicrobial activity and its physic-chemical characterization.

Keywords: Limacus flavus, mucus, slug, antimicrobial peptide, bioactive molecules, resistance, microorganisms 


\section{INTRODUCTION}

Antimicrobial resistance (AMR) is considered one of the major crises in the public health system worldwide, where attempts are made to suppress bacteria resistance to drugs [1]. For the past 30 years, antimicrobial peptides (AMPs) have been considered as a potential source of development of new antimicrobial drugs, specifically for multi-resistant-drugs. Although, evolutionarily, microorganisms, whether bacteria, viruses, fungi or parasites, suffer selective antimicrobial pressure, leading them to develop and acquire a natural resistance to existing drugs [2]. Thus, due to inefficient control of infections, the geographical movement of infected people and animals and environmental contamination increase resistance locally and globally [3].

AMPs are mostly amphipathic and cationic molecules, structurally composed of 5 to 100 amino acid residues [4,5]. They are produced by both vertebrates and invertebrates and plants [4]. They have a broad spectrum of activity against bacteria, fungi, protozoa and viruses [4,6], according to their physicalchemical structure, which includes their size, electrical charge, amphipathic structure, hydrophobicity and the mode of action [4,6]. Also, AMPs can have more than one biological response exhibiting a range of different activities, such as antiparasitic, antitumor, antiobesity, stimulates cell proliferation, angiogenesis and Vasculongenian properties, promotes wound healing and inhibits the inflammatory response, in addition to acting directly in the body's antimicrobial defense. As it presents a variety of responses, AMPs have been increasingly studied; both to complement information about their functional properties and for pharmacological industrial interest [7].

Mucus is a complex mixture of products of great variety qualitatively and quantitatively, which forms a mechanical and biological barrier on an epithelial surface. This fluid is considered biphasic because it has an aqueous phase and a gel phase [8]. Being composed of a high water content and presents molecules of high molecular weight, in addition to gel-forming molecules [9]. For example, glycoproteins (mucins)[9], proteins, proteoglycans and lipids [10]. Its composition is similar between the most derived vertebrates and invertebrates [11].

Mucus is considered a highly versatile material, being produced for several functions: breathing $[9,12]$, ionic and osmotic regulation [9,12], reproduction (gamete exchange) [9,12], nest production [9], excretion [9], communication (hormones and smells) [9,12], feeding [9,12], locomotion [13], adhesion to surfaces [12], hydration [10,14-16], mechanical protection and disease resistance $[9,10,12,17,18]$.

Some of the research related to mucus is of snails and slugs, which have been in human health since ancient times, with their importance in folk and traditional medicine [19]. Snail mucus is well described in the literature, with biological and chemical properties in detail [19]; however, this does not occur in terrestrial slugs.

In slugs, mucus contains lectins [20], mucopolysaccharide and glycoprotein [20]. In the Arion ater slug, Cottrell et al. [21] found glycosaminaglycan with high concentrations of galactosamine and galactose. In addition, Otsuka-Fuchino et al. [22] reported in the Achatina fulica mucus a glycoprotein, achatin, which has antimicrobial activity against Gram-positive and Gram-negative bacteria. Some authors such as Iguchi et al., [14], Kubota et al. [15], Otsuka-Fuchino et al. [22], Toledo-Piza [17,18] and Araujo [23] demonstrated that slug mucus has antimicrobial peptide.

One of the most recent researches was carried out by the group of Li et al [24] where it was possible to carry out the transcriptome of the total body of the slug Limacus flavus with the next generation sequencing technique. The data resemble similarity with Aplysia californica, Lottia gigantean and Crassostrea gigas sequences. Furthermore, AMPs and protein-like were identified, such as lysozymes (antibacterial activity), defensins (antibacterial, antifungal and antiviral activity), thaumatin-like protein (antifungal activity), peritrophin (antibacterial activity), cystatin (antibacterial, antifungal and antiviral activity) and others fragments of AMPs which have antimicrobial activity and wound healing functions. 


\section{MATERIALS AND METHOD}

\subsection{YELLOW SLUG}

Adult specimens of L. flavus were collected in São Paulo/SP, Brazil, at Vila Sônia neighborhood (2359'54'S 46 73 '44'W). They were stored alive in plastic compartments for transportation to the Laboratory of Applied Toxinology (LETA), at Butantan Institute, and stored in plastic boxes (33.0 x 21.8 $\mathrm{x} 10.3 \mathrm{~cm}$ ) with pierced lids at $20-25^{\circ} \mathrm{C}$. They were fed two times a week, with mice's ration or lettuce; and in a plastic container with wet cotton. The cleansing of the materials was made three times a week.

\subsection{MUCUS EXTRACTION}

The animals were kept for three days without food before mucus extraction. They were submitted to thermal shock, which consist the submersion of each one in cold ultrapure water. Subsequently, the mucus was obtained by scraping the body with the help of a wooden spatula and stored in a sterile container (Figure 1). The material was subjected to lyophilization and stored at $-80{ }^{\circ} \mathrm{C}$.

\subsection{REVERSE-PHASE HIGH-PERFORMANCE LIQUID CHROMATOGRAPHY (RP-HPLC)}

Mucus was homogenized with $5.0 \mathrm{~mL} \mathrm{10 \%} \mathrm{DMSO} \mathrm{for} 2 \mathrm{~min}$ on a shaker, centrifuged (Centrifuge5804R Eppendorf $®$ Instruments, Inc.) for $5 \mathrm{~min}$, at $14000 \mathrm{x}$ g at $4{ }^{\circ} \mathrm{C}$. RP-HPLC purification was performed with a Shim-pack XR-ODS preparative column (5 $\mu \mathrm{m} ; 20 \mathrm{~mm} ; 250 \mathrm{~mm}$, Shimadzu®), coupled with a preparative Shimadzu® system, with a gradient of $0 \%$ to $80 \%$ acetonitrile $(0.1 \%$ TFA), over 60 min, with flow rate of $8 \mathrm{ml} / \mathrm{min}$. Fractions were collected manually and the absorbance monitored at $225 \mathrm{~nm}$. Each peak fraction collected was vacuum-dried (Savant Instrument Inc $®$ ), reconstituted in $1 \mathrm{~mL}$ ultrapure water and evaluated by antimicrobial activity assays.

\subsection{MICROBIAL STRAINS}

Bacterial and fungal strains were obtained from the collection of microorganisms of the Laboratory for Applied Toxinology (LETA) of the Butantan Institute (São Paulo, Brazil). The bioassays were performed with Gram-positive bacteria Bacillus megaterium ATCC10778, Bacillus subtilis ATCC6633, Micrococcus luteus A270, Staphylococcus aureus ATCC29213, Gram-negative Bacteria Enterobacter cloacae $\beta$-12, Escherichia coli SBS 363, Salmonella arizonae ATCC13314, Filamentous Fungi Aspergillus niger (isolated bread), Beauveria bassiana (isolated from mummified insect), Cladosporium sp (isolated bread) and Yeast Candida glabrata IOC4565, Candida krusei IOC4559 and Cryptococcus neoformans var. neoformans B-350 1A.

\subsection{ANTIMICROBIAL ASSAYS}

The antimicrobial effects of the fraction were evaluated by liquid growth inhibition assays as Riciluca [25], using Bacillus megaterium ATCC10778, Bacillus subtilis ATCC6633, Micrococcus luteus A270, Staphylococcus aureus ATCC29213, Enterobacter cloacae $\beta-12$, Escherichia coli SBS 363, Salmonella arizonae ATCC13314, Aspergillus niger (isolated bread), Beauveria bassiana (isolated from mummified insect), Cladosporium sp (isolated bread), Candida glabrata IOC4565, Candida krusei IOC4559 and Cryptococcus neoformans var. neoformans B-350 1A. Bacteria were cultured in poor nutrient broth (PB) (1.0 g peptone in $100 \mathrm{ml}$ of water containing $86 \mathrm{mM} \mathrm{NaCl}$ at $\mathrm{pH} 7.4 ; 217 \mathrm{mOsM}$ ) and fungus and yeasts were cultured in poor potato dextrose broth (1/2 PDB: $1.2 \mathrm{~g}$ potato dextrose in $100 \mathrm{ml}$ of $\mathrm{H}_{2} \mathrm{O}$ at $\mathrm{pH}$ 5.0; $79 \mathrm{mOsM}$ ). Determination of antimicrobial peptide was performed using 5-fold microtiter broth dilution assay in 96-well sterile plates at a final volume of $100 \mu \mathrm{L}$. Mid-log phase culture was diluted to a final concentration of $5 \times \llbracket 10 \rrbracket \wedge 4 \mathrm{CFU} / \mathrm{mL}$ for bacteria and $5 \times \llbracket 10 \rrbracket \wedge 5 \mathrm{CFU} / \mathrm{mL}$ for fungus and yeast, as 
Segura-Ramírez \& Silva Júnior [26]. Dried fractions were dissolved in $200 \mu \mathrm{L}$ of ultrapure water and 20 $\mu \mathrm{L}$ aliquoted into each well with $80 \mu \mathrm{L}$ of the microbial dilution. The assays were executed in duplicate. The microplates were incubated for $18 \mathrm{~h}$ at $30{ }^{\circ} \mathrm{C}$, under constant agitation. Growth inhibition was determined by measuring absorbance at $595 \mathrm{~nm}$.

\subsection{HEMOLYTIC ASSAY}

Human erythrocytes from a healthy adult donor were collected with $0.15 \mathrm{M}$ citrate buffer and washed three times by centrifugation $\left(800 \mathrm{x} \mathrm{g}, 15 \mathrm{~min}, 4{ }^{\circ} \mathrm{C}\right.$ ), the supernatant was discarded. Aliquots of $100 \mu \mathrm{L}$ in a $3 \%(\mathrm{v} / \mathrm{v})$ suspension of washed erythrocytes in $0.15 \mathrm{M}$ phosphate-buffered saline (PBS) was incubated with the fraction in a U-bottom 96-well microplate for $3 \mathrm{~h}$ at $37^{\circ} \mathrm{C}$ with constant shaking. The supernatant was transferred to a 96-well flat microplate and the hemolysis was measured by the absorbance at $405 \mathrm{~nm}$ of each well in a microplate reader Victor ${ }^{3}$ (1420 Multilabel Counter/Victor3, Perkin Elmer). The hemolysis percentage was expressed in relation to a $100 \%$ lysis control (erythrocytes incubated with $0.1 \%$ triton X-100); PBS was used as a negative control. The equation used for $\%$ of hemolysis was: \% Hemolysis: [(Abs pep - Abs PBS)/Abs Triton 0.1\% - Abs PBS) *100]

\subsection{MASS SPECTROMETRY AND BIOINFORMATICS ANALYSIS}

Samples were suspended in $15 \mu \mathrm{L}$ of $0.1 \%$ formic acid solution and analyzed by liquid chromatography coupled to tandem mass spectrometry (LC-MS/MS) on Thermo Scientific ${ }^{\text {TM }}$ LTQ XL ${ }^{\text {TM }}$ - ETD mass spectrometer (Thermo Fisher Scientific, Bremen, Germany) coupled to an Easy-nLC 1000 (Thermo Fisher Scientific, Bremen, Germany). The samples were $(10 \mu \mathrm{L})$ automatically injected into a Júpiter C18 $(10 \mu \mathrm{m}$, $100 \mu \mathrm{m}$ x $50 \mathrm{~mm}$ ) pre-column (Phenomenex) coupled to a $\mathrm{C} 18$ capillary analytical reverse phase column. A linear gradient of 5 to $95 \%$ acetonitrile/formic acid $0,1 \%$ for 30 minutes and a flow rate of $140 \mathrm{~nL} / \mathrm{min}$ was used. The ionization source was operated in positive mode, which detects positively charged ions. The spectra were collected and analyzed in Xcalibur 2.0 software (Thermo Electron, USA). The deconvolution of the $\mathrm{m} / \mathrm{z}$ values to obtain the molecular weight of the protein was performed in the software MassLynx V4.1 Walters® (accessed on 20th August 2020) and PEAKS®X+ Studio software (v10.5; Bioinformatics Solutions, Waterloo, ON, Canada). Also, peptides were searched against the NCBI database using the PEAKS DB tool with Gastropoda, Limax and Limacus flavus databases and compared to Li et al. [24], KEGG pathways. The physicochemical parameters were evaluated in the bioinformatics tool ChemDraw and Chem3D Professional 16.0.4 and with the online programs as PepCalc (https://pepcalc.com/), PepDraw (http://pepdraw.com/), all accessed on 22th August 2020 and ProteinBlast (https://blast.ncbi.nlm.nih.gov) tool.

\section{RESULTS}

\subsection{FRACTIONATION OF THE MUCUS AND ANTIMICROBIAL SCREENING}

The mucus extract from three adult specimens was processed as previously described. The resulting supernatant was applied to a reverse-phase HPLC and was isolated 3 fractions (Figure 2) with antimicrobial activity when analyzed in liquid growth inhibitory assays. All fractions were tested against 13 microorganisms' strains and showed some type of antimicrobial activity (Table 1). Fractions were named as LFMP-Fp001, LFMP-Fp002 and LFMP-Fp003. Fractions, LFMP-Fp001 and LFMP-Fp002, inhibited only $B$. subtillis and $A$. niger however LFMP-Fp003 showed greater activities, inhibiting $B$. subtillis, C. neoformans, E. cloacae and M. luteus A270. 


\subsection{HEMOLYTIC ASSAY}

All fractions were tested for hemolytic assay, no hemoglobin release was observed. The three fractions show non-toxicity activity against human erythrocytes.

\subsection{MASS SPECTROMETRY AND BIOINFORMATICS ANALYSIS}

By the deconvolution of the fractions by PeaksX+ software, all fractions presented mass less than $3 \mathrm{kDa}$. Characterization of LFMP-Fp001 primary structure by MS/MS exhibited 636.74 Da with sequence YLRW (Figure 3); LFMP-Fp002, 560.6 Da sequence DLQW (Figure 4) and LFMP-Fp003, 560.6 Da with sequence WLGH (Figure 5). When LFMP-Fp001 was processed in NCBI database (Blastp) (Table 2) LFMP-FP001 showed similarities to Aplysia californica, Biophalaria glabrata, Lottia gigantea and Pomacea canaliculata proteins. When compared to KEGG pathways (Table 3), none of the proteins listed are related to immune system pathways. When compared to NCBI database (Table 4) the sequence of LFMP-Fp002 matched with 6 organisms, A. californica, B. glabrata, Elysia chlorotica, Littorina littorea, Lottia gigantean and $P$. canaliculata. Most of the proteins found are isoforms or uncharacterized/hypothetical sequences. When compared to KEGG pathways, L. littorea presents two tolllike receptors proteins. In addition, $P$. canaliculata exhibited similarities with CD109 antigen-like proteins and Mitogen-activated protein kinase 13-like.The fraction LFMP-FP003 showed similarities to the same organisms as the fraction LFMP-FP001, being B. glabrata and $P$. canaliculata with most proteins identifications (Table 5). Presenting the same characteristics, most of the sequences are not identified and not related to KEGG pathways.

\subsection{STRUCTURE AND PHYSIC-CHEMICAL CHARACTERIZATION}

Sequences similarity searches with Basic Local Alignment Search Tool (BLAST) were performed but there was no significant similarity found for the three fractions, due to its short sequence predicted. Physical and chemical characteristics were predicted by bioinformatics online programs which net charge, theoretical isoelectric point $(\mathrm{pI})$ and solubility were predicted. LFMP-Fp001 is a cationic molecule (net charge of 1) due to the presence in its structure of one tyrosine (Y), one leucine (L), one positively charged arginine residue $(\mathrm{R})$ and one tryptophan $(\mathrm{W})$. Furthermore the peptide has a pI of 9.57, indicating that this is the $\mathrm{pH}$ value at which its net charge is equal to 0. By estimating its solubility, LFMP-Fp001 has poor water solubility, considerate a hydrophobic AMP. LFMP-Fp002 is an anionic peptide (net charge of 1) due to one negatively charged aspartic acid (D), one leucine (L), one glutamine (Q) and one tryptophan (W) and presents an iso-electric point of $\mathrm{pH}$ 0.67. Based on the iso-electric point, the number of charged residues, and the peptide length of four residues, this peptide might have good water solubility, an hydrophilic AMP. LFMP-Fp003 is a neutral peptide (net charge zero) due to its sequence, as one tryptophan $(\mathrm{W})$, one leucine $(\mathrm{L})$, one glycine $(\mathrm{G})$ and one histidine $(\mathrm{H})$, presents an iso-electric point of pH 7.69 and has poor water solubility, being considerate an hydrophobic AMP.

\section{DISCUSSION}

One of the main crises in the public health system worldwide is the antimicrobial resistance (AMR) [1] and since the Antibiotic Revolution, natural products from a wilde range of organism are being studied for suppress diseases and deaths [27]. The raw mucus presented an elastic consistency and translucentyellowish color, same described by Boffi [28] and Barker [29] and after liophilization it presented a cotton-like texture. Thermal shock method was chosen for being the less aggressive treatment to collect more material of the species, as described by Pemberton [30], otherwise saline solution could extract unlike residues. Among the organisms tested, it is noted that the mucus showed greater inhibition for filamentous fungi and Gram-positive bacteria, followed by Gram-negative bacteria and fungi yeasts. The assay established sensitivity to a range of microorganisms which can be related as probable pathogens that the Phylum Mollusca can be exposed in the environments [31]. The Phylum Mollusca is one of the most 
diverse phyla in the animal kingdom; they originated from the Cambrian period [32] and have undergone few changes in the course of evolution [33]. Its irradiation allowed colonization in various environments (ocean, fresh water and land) [34], enriched with pathogens, such as viruses, fungi and bacteria. Currently it is estimated that mucus presented antimicrobial properties beyond the breathing and hydration functions, communication, locomotion and adhesion in surfaces [19]. All the fractions were tested for hemolytic assay, showing. These data suggest that the mechanism of action of the L. flavus mucus does not involve the disruption of cell membranes. Once you consider developing novel antibiotics for human application, the drug itself must show low toxicity against erythrocytes [35], which all three fractions demonstrated.

When analyzed by mass spectrometry and bioinformatics tools, LFMP-Fp001 did not show similarities with KEGG pathways of Li et al.[24], instead when the BLAST was proceed, it showed similarities with close organisms although most of the proteins were uncharacterized/hypothetical. Comparing the results from BLAST and KEGG pathways, LFMP-Fp002 can be related to two proteins matches: L. littorea presents two toll-like receptors proteins and $P$. canaliculata, CD109 antigen-like and Mitogen-activated protein kinase 13-like. Toll-like receptor signaling pathway (KO04620), which recognizes pathogenassociated molecular patterns derived from microbes. CD109 antigen is related to T-cell, once these cells receptors are activated, it initiates the signaling process of cascades to respond to the infection; and Mitogen-activated protein in humans is an important role in the cascades of cellular responses evoked by extracellular stimuli such as pro-inflammatory cytokines or physical stress. Once applied these proteinslike to L. flavus slugs, they may have a similar processes, since these organism is constantly exposed to a wide range of microbes and external stresses. The fraction LFMP-FP003 faced the same situation as LFMP-FP001, although it presented similarities with some invertebrates, none of the proteins were characterized, same to proteins identified to KEGG pathways. The three fractions had different physicchemical characteristics and when thought of a novel antibiotic, these characteristics are important when it comes to the variety of microorganisms, target and biological responses, since AMR is of global health problem.

\section{CONCLUSION}

In conclusion, we isolated, fractionated and characterized the three antimicrobial peptides of the mucus of yellow slug L. flavus. The three peptides LFMP-FP001, LFMP-FP002 and LFMP-FP003 presents a wide range of antimicrobial activity, showing more sensibility to Gram-positive bacteria and filamentous fungi, following to Gram-negative bacteria and fungi yeast. Physic-chemical characteristics were elucidated, which LFMP-FP001 is featured as a cationic AMP, LFMP-FP002 an anionic AMP and LFMP-FP003 neutral AMP (no net charge). Furthermore, none of the molecules has a cytotoxic activity against human erythrocytes, suggesting that the three AMPs have potential for a novel antibiotic. Thus, further investigations will be carried out on multidrug resistant bacteria and mode of action of the three molecules, considering antimicrobial resistance is one of the major public health problems. Finally, it is worth highlight that this work complements the literature of L. flavus and indicates that the mucus of this species can be a source of antimicrobial molecules.

\section{ETHICS APPROVAL AND CONSENT TO PARTICIPATE}

This research was approved and performed in accordance with the Ethical Principles in Animal Research adopted by the Ethics Committee in the Use of Animals of Butantan Institute ( $\mathrm{N}^{\circ}$ 5649250717) and Plataforma Brasil CAAE N¹9403819.1.0000 


\section{FUNDING}

This research was funded by the Research Support Foundation of the State of São Paulo (FAPESP/CeTICS) (Grant No. 2013/07467-1), by the Brazilian National Council for Scientific and Technological Development (CNPq) (Grant No. 472744/2012-7), by the Coordenação de Aperfeiçoamento de Pessoal de Nível Superior - Brasil (CAPES) - Finance Code 001 and by the Biomedical Sciences Institute - São Paulo University ISNI: 0000000406355304.

\section{CONFLICT OF INTEREST}

The authors declare no financial or commercial conflict of interest.

\section{ACKNOWLEDGEMENTS}

Conceptualization, P.Y.H. and P.I.S.J.; Data curation, P.Y.H.; Formal analysis, P.I.S.J.; Funding acquisition, P.I.S.J.; Investigation, P.Y.H.; Methodology, P.I.S.J.; Project administration, P.I.S.J.; Resources, P.I.S.J.; Supervision, P.I.S.J.; Validation, P.Y.H. and P.I.S.J.; Writing-original draft, P.Y.H.; Writing-review and editing, P.Y.H. and P.I.S.J.

Special thanks to Dr. Milton Yutaka Nishiyama Junior (Center for Bioinformatics and Computational Biology, Butantan Institute, São Paulo (SP), Brazil) for helping us with the databases.

\section{REFERENCES}

[1] World Health Organization. WHO report on surveillance of antibiotic consumption: 2016-2018 early implementation. 2018.

[2] Holmes AH, Moore LSP, Sundsfjord A, Steinbakk M, Regmi S, Karkey A, et al. Understanding the mechanisms and drivers of antimicrobial resistance. The Lancet. Lancet Publishing Group. 2016;387:176-87. 10.1016/S0140-6736(15)00473-0

[3] McEwen SA, Collignon PJ. Antimicrobial Resistance: a One Health Perspective. In: Antimicrobial Resistance in Bacteria from Livestock and Companion Animals. ASM Press. 2018;521-47. 10.1128/9781555819804.ch25

[4] Zhang C, Yang M, Ericsson AC. Antimicrobial Peptides: Potential Application in Liver Cancer. Front Microbiol. 2019;10:1257. 10.3389/fmicb.2019.01257

[5] Barreto-Santamaría A, Rivera ZJ, García JE, Curtidor H, Patarroyo ME, Patarroyo MA, et al. Shorter Antibacterial Peptide Having High Selectivity for E. coli Membranes and Low Potential for Inducing Resistance. Microorganisms. 2020;8:867. 10.3390/microorganisms8060867

[6] Boparai JK, Sharma PK. Mini Review on Antimicrobial Peptides, Sources, Mechanism and Recent Applications. Protein Pept Lett. 2019;27:4-16. 10.2174/0929866526666190822165812

[7] Pasupuleti M, Schmidtchen A, Malmsten M. Antimicrobial peptides: key components of the innate immune system. Crit Rev Biotechnol. 2012;32:143-71. 10.3109/07388551.2011.594423 
[8] Martins ALP, Jamami M, E Costa D. Estudo Das Propriedades Reológicas Do Muco Brônquico De Pacientes Submetidos A Técnicas De Fisioterapia Respiratória. Rev. Bras. Fisioter. 2005;9:33-9. JSSN 1413-3555

[9] Shephard KL. Functions for fish mucus . Reviews in Fish Biology and Fisheries. Kluwer Academic Publishers; 1994; 4:401-29. 10.1007/BF00042888

[10] Voynow JA, Mengr BKR. Mucins, mucus, and sputum. Chest. 2009;135:505-12. 10.1378/chest.08-0412

[11] Allen A, Bell A, Mantle M, Pearson JP. The structure and physiology of gastrointestinal mucus. Advances in experimental medicine and biology. Springer, Boston, MA. 1982;144:115-33. 10.1007/9781-4615-9254-9_15

[12] Cone RA. Barrier properties of mucus. Advanced Drug Delivery Reviews. Elsevier. 2009;61:7585. 10.1016/j.addr.2008.09.008

[13] Landauer MR, Chapnick SD. Responses of terrestrial slugs to secretions of stressed conspecifics. Psychol Rep. 1981;49:617-8. 10.2466/pr0.1981.49.2.617

[14] Iguchi SMM, Akawa T, Matsumot JJ. Antibacterial Activity Of Snail Mucus Mucin. Camp Biochon Phpol. 1982;12:571-4. 0300-9629 82 030571-04103.00.0

[15] Kubota Y, Watanabe Y, Otsuka H, Tamiya T, Tsuchiya T, Matsumoto JJ. Purification and characterization of an antibacterial factor from snail mucus. Comp Biochem Physiol Part C Comp Pharmacol. 1985;82:345-8. 10.1016/0742-8413(85)90173-2

[16] Li D, Graham LD. Epidermal secretions of terrestrial flatworms and slugs: Lehmannia valentiana mucus contains matrilin-like proteins. Comp Biochem Physiol - B Biochem Mol Biol. 2007;148:231-44. 10.1016/j.cbpb.2007.06.001

[17] Toledo Piza, AR de. Muco de Phyllocaulis boraceiensis: efeito microbiológico e análise bioquímica. 2007.

[18] Toleddo Piza, AR. Avaliação e caracterização proteica do muco de Phyllocaulis boraceiensis sobre a capacidade proliferativa de fibroblastos, células endoteliais e em modelos de cicatrização. Biblioteca Digital de Teses e Dissertações da Universidade de São Paulo; 2012. 10.11606/T.87.2012.tde-21092012102841

[19] Cilia G, Fratini F. Antimicrobial properties of terrestrial snail and slug mucus. Journal of Complementary and Integrative Medicine. De Gruyter. 2018;15. 10.1515/jcim-2017-0168

[20] Deyrup Olsen I, Luchtel DL, Martin AW. Components of mucus of terrestrial slugs (Gastropoda). Am J Physiol - Regul Integr Comp Physiol. 1983;14:R448-R452. 10.1152/ajpregu.1983.245.3.R448

[21] Cottrell JM, Henderson IF, Wright DJ. Studies on the glycosaminoglycan component of trail mucus from the terrestrial slug, Arion ater L. Comp Biochem Physiol -- Part B Biochem. 1994;107:28596. 10.1016/0305-0491(94)90051-5

[22] Hisako Otsuka-Fuchino, Yoichi Watanabe, Chikako Hirakawa, Toru Tamiya, Matsumoto JJ, Takahide Tsuchiya. Bactericidal action of a glycoprotein from the body surface mucus of giant African 
snail. Comp Biochem Physiol Part C Comp Pharmacol. 1992;101:607-13. 10.1016/0742-8413(92)90094$\mathrm{n}$

[23] Araujo, RL. Estudo do potencial antimicrobiano do muco de Phyllocaulis boraceiensis. Biblioteca Digital de Teses e Dissertações da Universidade de São Paulo; 2016. 10.11606/D.87.2016.tde-20102016094519

[24] Li Z, Yuan Y, Meng M, Li S, Deng B, Wang Y. The transcriptome analysis of the whole-body of the gastropod mollusk Limax flavus and screening of putative antimicrobial peptide and protein genes. Genomics. 2020;112:3991-9. 10.1016/j.ygeno.2020.06.046

[25] Riciluca KCT. Peptídeos bioativos do plasma de Acanthoscurria rondoniae. Biblioteca Digital de Teses e Dissertações da Universidade de São Paulo; 2016. 10.11606/T.87.2016.tde-29082016-090342

[26] Segura-Ramírez P, Silva Júnior P. Loxosceles gaucho Spider Venom: An Untapped Source of Antimicrobial Agents. Toxins (Basel). 2018;10:522. 10.3390/toxins10120522

[27] Michael, CA, Dominey-Howes D, Labbate M. The Antimicrobial Resistance Crisis: Causes, Consequences, and Management. Front Public Heal. 2014;2:145. 10.3389/fpubh.2014.00145

[28] Boffi, AV. Moluscos brasileiros de interesse médico e econômico. Fundação de Amparo à Pesquisa do Estado de São Paulo; 1979;376.

[29] Barker, Gary M. (Ed.). The biology of terrestrial molluscs. CABI, 2001.

[30] Pemberton RT. Haemagglutinins from the Slug Limax flavus. Vox Sang. 1970;18:74-6. 10.1111/j.1423-0410.1970.tb01432.x

[31] Bueno Dias G. Caracterização estrutural e química das sementes, folhas e frutos de diferentes espécies do gênero Capsicum L. e sua relação com mecanismo de defesa. Universidade Estadual Do Norte Fluminense Darcy Ribeiro; 2012.

[32] Gerdol M, Fujii Y, Hasan I, Koike T, Shimojo S, Spazzali F, et al. The purplish bifurcate mussel Mytilisepta virgata gene expression atlas reveals a remarkable tissue functional specialization. BMC Genomics. 2017;18:1-24. 10.1186/s12864-017-4012-z

[33] Wanninger A, Wollesen T. The evolution of molluscs. Biol Rev. 2019;94:102-15. 10.1111/brv.12439

[34] Brown KM, Lydeard C. Mollusca: Gastropoda. In: Ecology and Classification of North American Freshwater Invertebrates. Academic Press. 2010; 277-306. 10.1016/B978-0-12-374855-3.00010-8

[35] Oddo A, Hansen PR. Hemolytic activity of antimicrobial peptides. Methods in Molecular Biology. Methods

Mol Biol. Humana Press, New York, NY, 2017. 
bioRxiv preprint doi: https://doi.org/10.1101/2021.05.06.442857; this version posted June 28, 2021. The copyright holder for this preprint (which was not certified by peer review) is the author/funder, who has granted bioRxiv a license to display the preprint in perpetuity. It is made available under aCC-BY-NC-ND 4.0 International license.

\section{FIGURES}

Figure 1. Limacus flavus slug (A) Mucus extraction from the Limacus flavus slug by thermal shock and body scraping. (B) Lyophilized raw mucus stored in a conical centrifuge tube of $15.0 \mathrm{~mL}$ and $50.0 \mathrm{~mL}$.

A.

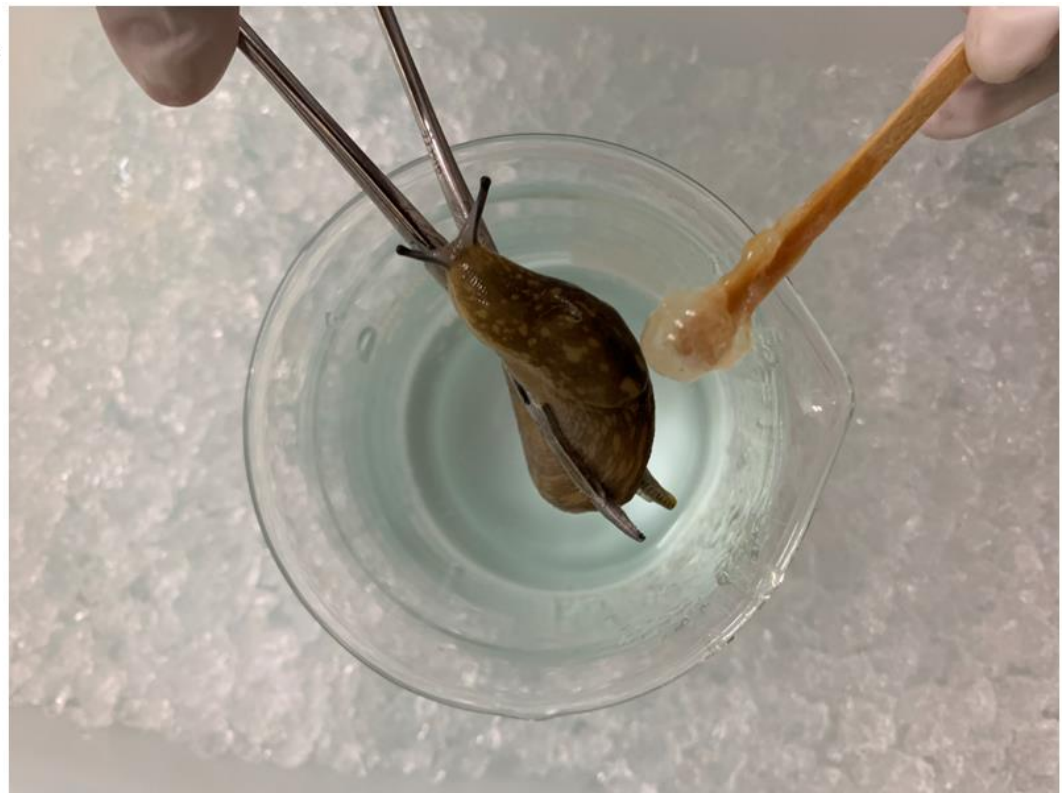

B.

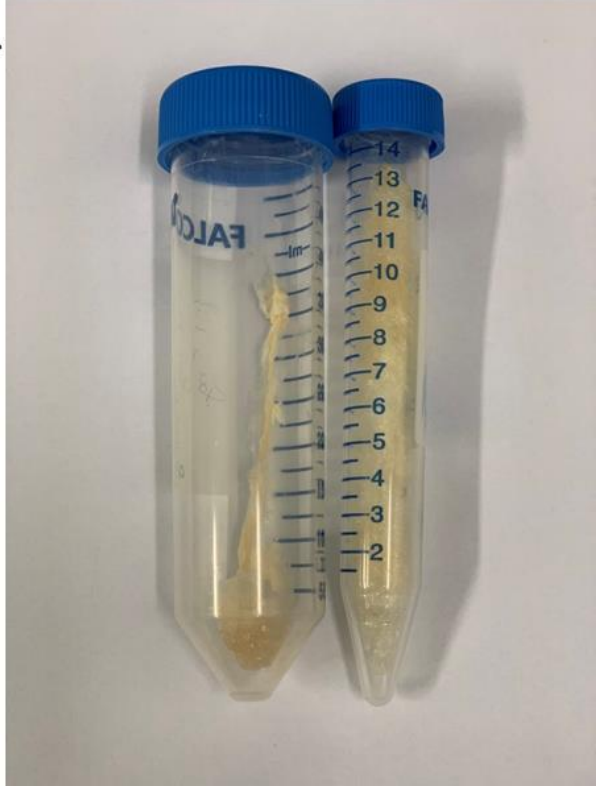

Figure 2. Fractionation of the Limacus flavus mucus extract in 10\% DMSO (eluted in $80 \%$ acetonitrile). Chromatographic fractionation profile by high performance liquid chromatography in reversed-phase using Shim-pack XR-ODS C18 preparative column of mucus treated with $10 \%$ DMSO, with flow $8.0 \mathrm{~mL} / \mathrm{min}$, in a linear gradient from $0 \%$ to $80 \%$ of ACN at $0.01 \%$ TFA in $60 \mathrm{~min} ; 225 \mathrm{~nm}$ absorbance.The enumerated peaks correspond to the fractions with antimicrobial activity.

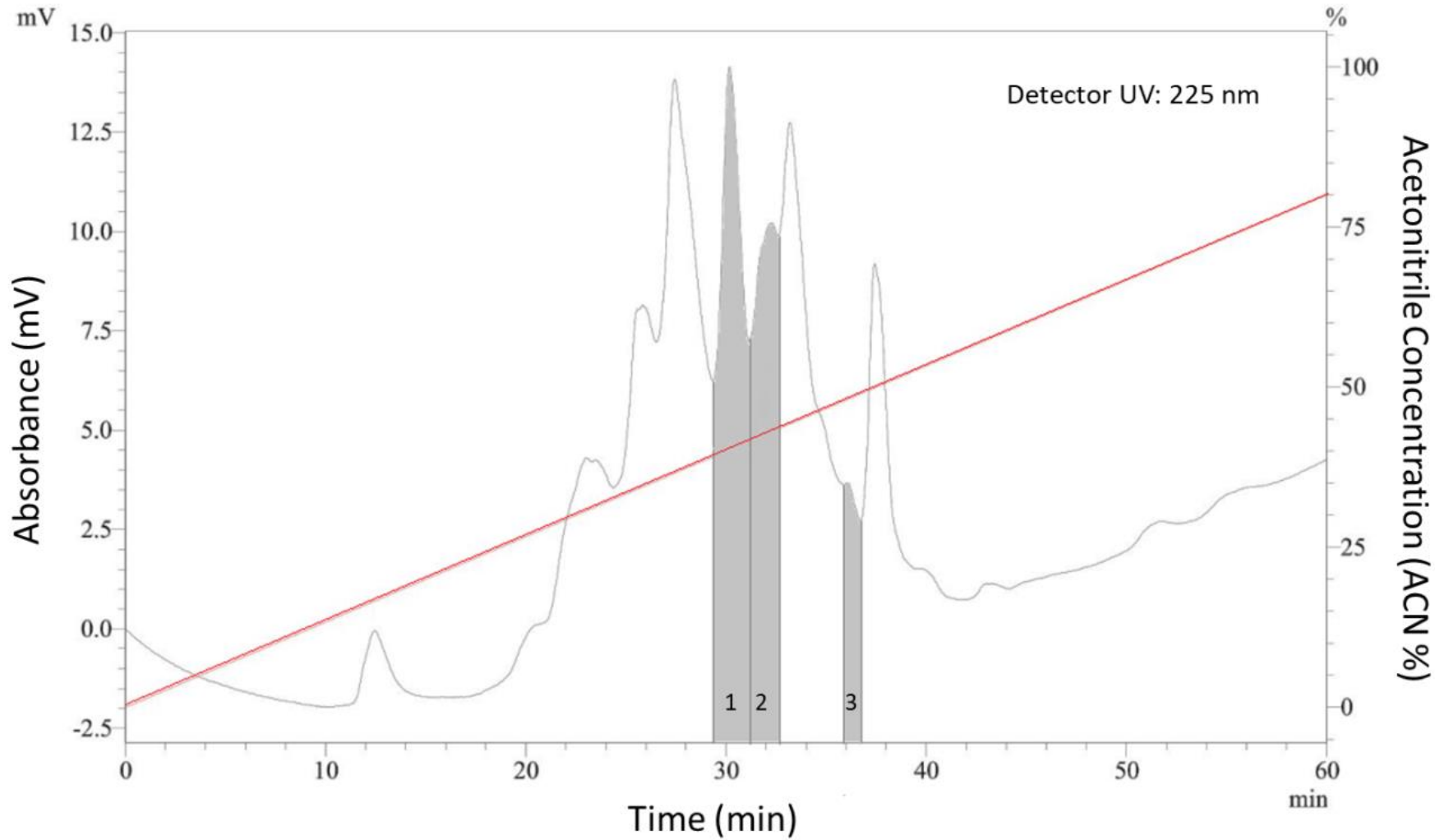


bioRxiv preprint doi: https://doi.org/10.1101/2021.05.06.442857; this version posted June 28, 2021. The copyright holder for this preprint (which was not certified by peer review) is the author/funder, who has granted bioRxiv a license to display the preprint in perpetuity. It is made available under aCC-BY-NC-ND 4.0 International license.

Figure 3. Deconvolution profile of the LFMP-Fp001 fraction after mass spectrometry (ESI-Q-Tof / MS) on Thermo Scientific ${ }^{\mathrm{TM}}$ LTQ XLTM - ETD mass spectrometer coupled to an Easy-nLC 1000 (A) Profile of the mass spectrometer using bioinformatic Peaks ${ }^{\circledR} \mathrm{X}+$ tool (B) Collision-induced dissociation (CID) spectrum of the de novo sequenced peptide. The ions relative to $-\mathrm{y}$ (red) and $-\mathrm{b}$ (blue) series indicated in the spectrum correspond to the amino acid sequence of the antimicrobial peptide, YLRW. The sequence is represented by standard amino acid code letters. (C) Ion matches profile of YLRW (D) Primary structure of YLRW accessed by the PerkinElmer ChemDraw Professional tool (E) Hydropathy parameters of LFMPFp001 by PepCalc tool.

A.

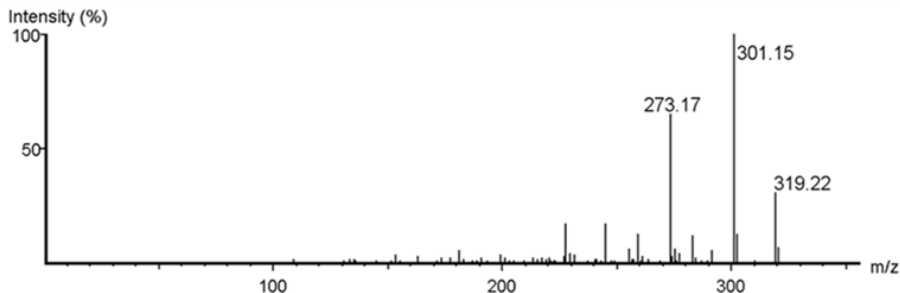

B. Intensity (\%) $\mathrm { Y } \longdiv { \mathrm { I } } \sqrt { \mathrm { R } } \sqrt { \mathrm { W } }$

C.

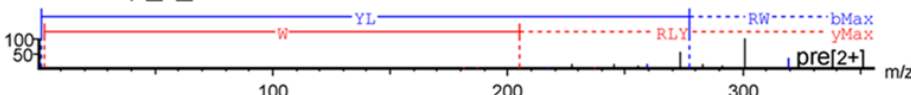

\begin{tabular}{|c|c|c|c|c|c|c|c|c|c|c|}
\hline & & & & & & & & & & \\
\hline$\#$ & b & b. $\mathrm{H}_{2} \mathrm{O}$ & b-NH3 & $b(2+)$ & Seq & $y$ & $y-\mathrm{H}_{2} \mathrm{O}$ & $y$-NH3 & $y(2+)$ & \# \\
\hline 1 & 164.07 & 146.06 & 147.04 & 82.54 & $Y$ & 474.28 & 456.27 & 457.26 & 237.25 & 4 \\
\hline 2 & 277.17 & 259.18 & 260.13 & 139.08 & L & 361.2 & 343.19 & 344.17 & 181.18 & 3 \\
\hline 3 & 433.26 & 415.25 & 416.23 & 217.17 & $R$ & 205.1 & 186.9 & 188.07 & 103.05 & 2 \\
\hline 4 & & & & & w & & & & & 1 \\
\hline
\end{tabular}

D.

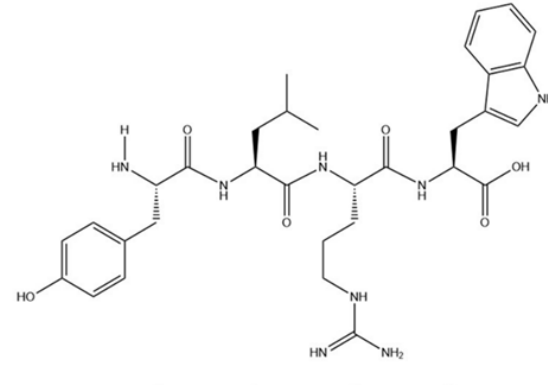

E.

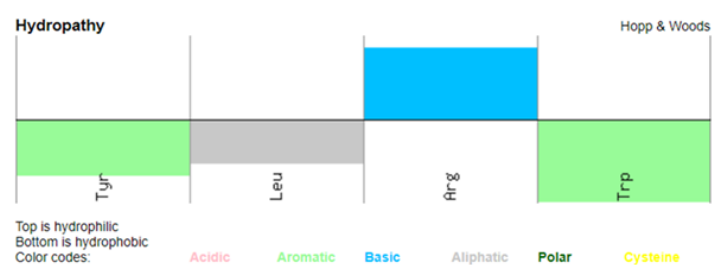

Figure 4. Deconvolution profile of the LFMP-Fp002 fraction after mass spectrometry (ESI-Q-Tof / MS) on Thermo Scientific ${ }^{\mathrm{TM}}$ LTQ XL ${ }^{\mathrm{TM}}$ - ETD mass spectrometer coupled to an Easy-nLC 1000 (A) Profile of the mass spectrometer using bioinformatic Peaks ${ }^{\circledR} X+$ tool (B) Collision-induced dissociation (CID) spectrum of the de novo sequenced peptide. The ions relative to $-\mathrm{y}$ (red) and -b (blue) series indicated in the spectrum correspond to the amino acid sequence of the antimicrobial peptide, DLQW. The sequence is represented by standard amino acid code letters. (C) Ion matches profile of DLQW (D) Primary structure of YLRW accessed by the PerkinElmer ChemDraw Professional tool (E) Hydropathy parameters of LFMPFp002 by PepCalc tool.

A. Intensity (\%)

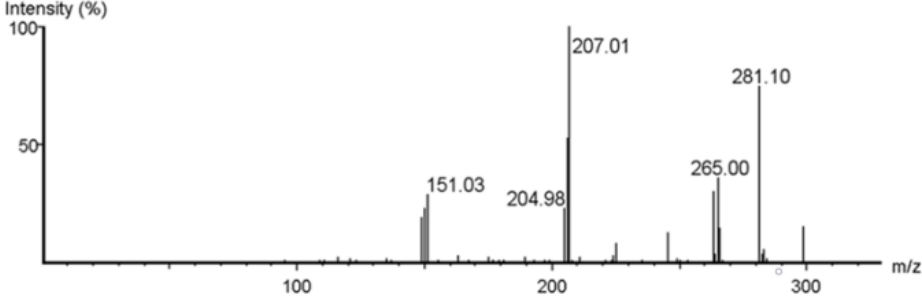

B. Intensity (\%) $\mathrm{D} \sqrt{\mathrm{L}} \sqrt[\mathrm{Q}]{\mathrm{W}}$

C.

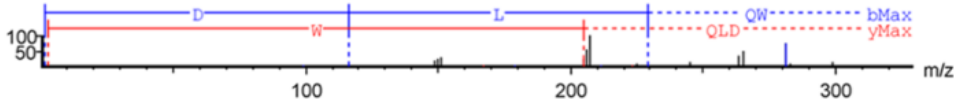

\begin{tabular}{ccccccccccc} 
Ion Match \\
\hline$\#$ & b & b-H2O & b-NH3 & b (2+) & Seq & y & y-H2O & $y$-NH3 & $y(2+)$ & $\#$ \\
\hline 1 & 116.03 & 98.02 & 98.97 & 58.52 & D & & & & & 4 \\
2 & 229.21 & 211.18 & 212.09 & 115.06 & L & 446.24 & 428.23 & 429.21 & 223.15 & 3 \\
3 & 357.18 & 339.17 & 340.15 & 179.13 & Q & 333.16 & 315.15 & 316.13 & 167.12 & 2 \\
4 & & & & & W & 204.98 & 189.09 & 188.07 & 103.05 & 1
\end{tabular}

D.

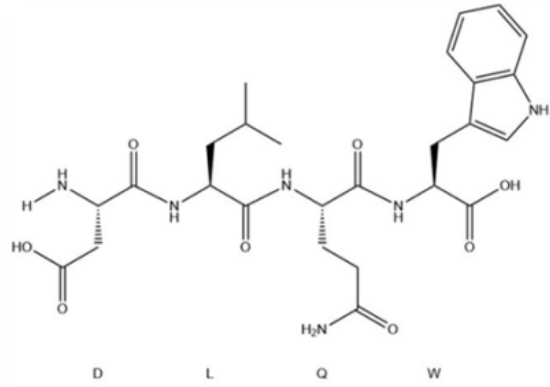

E.

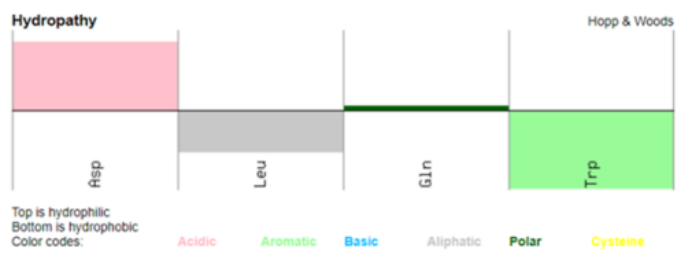


bioRxiv preprint doi: https://doi.org/10.1101/2021.05.06.442857; this version posted June 28, 2021. The copyright holder for this preprint (which was not certified by peer review) is the author/funder, who has granted bioRxiv a license to display the preprint in perpetuity. It is made available under aCC-BY-NC-ND 4.0 International license.

Figure 5. Deconvolution profile of the LFMP-Fp003 fraction after mass spectrometry (ESI-Q-Tof / MS) on Thermo Scientific ${ }^{\mathrm{TM}}$ LTQ XLTM - ETD mass spectrometer coupled to an Easy-nLC 1000 (A) Profile of the mass spectrometer using bioinformatic Peaks ${ }^{\circledR} \mathrm{X}+$ tool (B) Collision-induced dissociation (CID) spectrum of the de novo sequenced peptide. The ions relative to $-\mathrm{y}$ (red) and $-\mathrm{b}$ (blue) series indicated in the spectrum correspond to the amino acid sequence of the antimicrobial peptide, WLGH. The sequence is represented by standard amino acid code letters. (C) Ion matches profile of WLGH (D) Primary structure of YLRW accessed by the PerkinElmer ChemDraw Professional tool (E) Hydropathy parameters of LFMPFp003 by PepCalc tool.

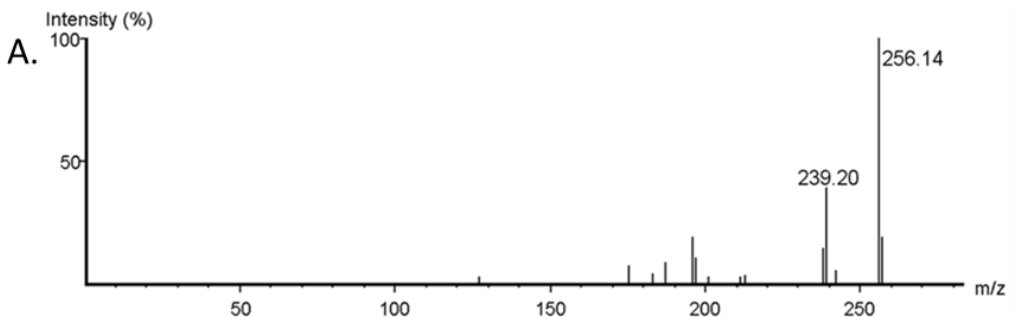

B. Intensity (\%) $\mathrm{W} / \mathrm{L}\lceil\mathrm{GH}$

C.

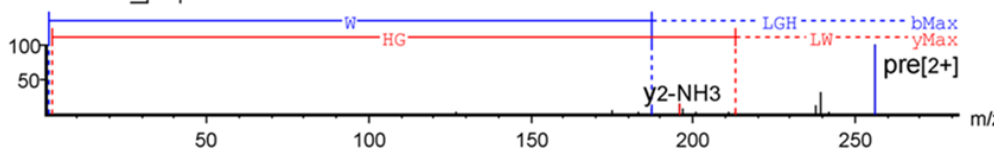

\begin{tabular}{ccccccccccc} 
Ion Match \\
\hline$\#$ & $\mathrm{~b}$ & $\mathrm{~b}-\mathrm{H} 2 \mathrm{O}$ & $\mathrm{b}-\mathrm{NH} 3$ & $\mathrm{~b}(2+)$ & Seq & $\mathrm{y}$ & $\mathrm{y}$-H2O & $\mathrm{y}$-NH3 & $\mathrm{y}(2+)$ & $\#$ \\
\hline 1 & 187.08 & 169.08 & 170.06 & 94.04 & $\mathrm{D}$ & & & & & 4 \\
2 & 300.17 & 282.16 & 283.14 & 150.59 & $\mathrm{~L}$ & 326.18 & 308.17 & 309.16 & 163.59 & 3 \\
3 & 357.19 & 339.18 & 340.17 & 179.1 & Q & 213.09 & 195.09 & 196.07 & 107.05 & 2 \\
4 & & & & & W & 156.08 & 138.07 & 139.05 & 78.54 & 1 \\
\hline
\end{tabular}

D.

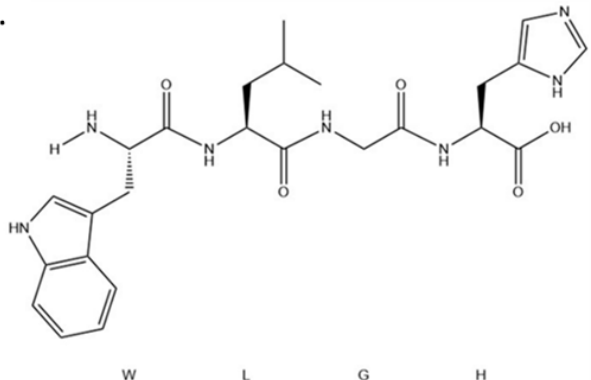

E.

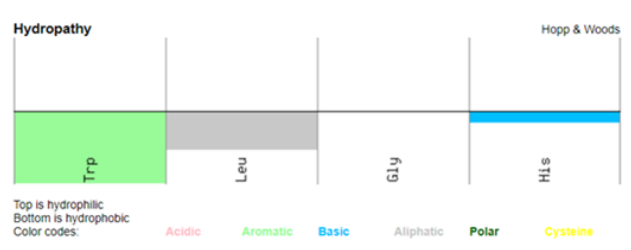

\section{TABLES}

Table 1. Antimicrobial activity in liquid growth of Limacus flavus slug mucus fractions collected by high-performance liquid chromatography in reversed-phase using Shim-pack XR- ODS C18 analytical column of mucus treated with 10\% DMSO, with flow $2.0 \mathrm{~mL} / \mathrm{min}$, in $60 \mathrm{~min} ; 225 \mathrm{~nm}$ absorbance. Tests carried out against Aspergillus niger (bread isolate), Beauveria bassiana, Bacillus megaterium ATCC10778, Bacillus subtilis ATCC6633, Candida glabrata IOC4565, Candida krusei IOC4559, Cladosporium sp (bread isolate), Cryptococcus neoformans, Enterobacter cloacae 363, Micrococcus luteus A270, Salmonella arizonae ATCC13314 and Staphylococcus aureus ATCC29213. The symbols: (+) inhibition of antimicrobial activity and (-) non-inhibition of antimicrobial activity.

\begin{tabular}{|c|c|c|c|c|}
\hline & \multirow[b]{2}{*}{ Microorganismos } & \multicolumn{3}{|c|}{ Fractions } \\
\hline & & 5 & 6 & 9 \\
\hline \multirow{4}{*}{$\begin{array}{c}\text { Gram- } \\
\text { positive } \\
\text { Bacteria }\end{array}$} & Bacillus megaterium ATCC10778 & - & - & - \\
\hline & Bacillus subtilis ATCC6633 & + & + & + \\
\hline & Micrococcus luteus A270 & - & - & + \\
\hline & Staphylococcus aureus ATCC29213 & - & - & - \\
\hline \multirow{2}{*}{$\begin{array}{c}\text { Gram- } \\
\text { negative }\end{array}$} & Enterobacter cloacae $\beta-12$ & - & - & + \\
\hline & Escherichia coli SBS 363 & - & - & - \\
\hline \multirow[t]{2}{*}{ Bacteria } & Salmonella arizonae ATCC13314 & - & - & - \\
\hline & Aspergillus niger (bread) & + & + & - \\
\hline \multirow[t]{3}{*}{ Fungi } & Beauveria bassiana & - & - & - \\
\hline & Cladosporium sp (bread) & - & - & - \\
\hline & Candida glabrata $10 C 4565$ & - & - & - \\
\hline \multirow[t]{2}{*}{ Yeast } & Candida krusei IOC4559 & - & - & - \\
\hline & Cryptococcus neoformans & - & - & + \\
\hline
\end{tabular}


bioRxiv preprint doi: https://doi.org/10.1101/2021.05.06.442857; this version posted June 28, 2021. The copyright holder for this preprint (which was not certified by peer review) is the author/funder, who has granted bioRxiv a license to display the preprint in perpetuity. It is made available under aCC-BY-NC-ND 4.0 International license.

Table 2. Aligments results of the fraction LFMP-Fp001 with ProteinBlast (blastp suite) from NCBI. Results with E value of 49, Total score of 19.3, Query cover of 100\% and restrict to Gastropoda (taxi: 6448), accessed in 11th December 2020.

\begin{tabular}{|c|c|c|}
\hline Description & Common Name & Accession \\
\hline \multirow{2}{*}{ Aplysia californica } & Uncharacterized protein LOC101864076 & XP_035826802.1 \\
\hline & Uncharacterized protein LOC101845475 & XP_012939634.1 \\
\hline \multirow{14}{*}{ Biomphalariaglabrata } & Uncharacterized protein LOC106064970 isoform X1 & XP_013079115.1 \\
\hline & Uncharacterized protein LOC106064970 isoform X2 & XP_013079124.1 \\
\hline & Uncharacterized protein LOC106064970 isoform X3 & XP_013079134.1 \\
\hline & Uncharacterized protein LOC106064970 isoform X4 & XP_013079142.1 \\
\hline & Uncharacterized protein LOC106064970 isoform X5 & XP_013079151.1 \\
\hline & Uncharacterized protein LOC106064970 isoform X6 & XP_013079160.1 \\
\hline & Uncharacterized protein LOC106064970 isoform X7 & XP_013079166.1 \\
\hline & Uncharacterized protein LOC106064970 isoform X8 & XP_013079174.1 \\
\hline & Uncharacterized protein LOC106064970 isoform X9 & XP_013079182.1 \\
\hline & Uncharacterized protein LOC106064970 isoform X10 & XP_013079228.1 \\
\hline & Uncharacterized protein LOC106064970 isoform X11 & XP_013079236.1 \\
\hline & Uncharacterized protein LOC106064970 isoform X12 & XP_013079252.1 \\
\hline & Chondroitin sulfate proteoglycan 4-like & XP_013095064.1 \\
\hline & Uncharacterized protein LOC106070666 & XP_013086064.1 \\
\hline Lottia gigantea & Hypothetical protein LOTGIDRAFT_233112 & XP_009056900.1 \\
\hline \multirow{17}{*}{ Pomacea canaliculata } & Microtubule-actin cross-linking factor 1-like isoform X1 & XP_025111011.1 \\
\hline & Microtubule-actin cross-linking factor 1 -like isoform X2 & XP_025111012.1 \\
\hline & Microtubule-actin cross-linking factor 1 -like isoform X3 & XP_025111014.1 \\
\hline & Microtubule-actin cross-linking factor 1 -like isoform X14 & XP_025111027.1 \\
\hline & Microtubule-actin cross-linking factor 1 -like isoform X4 & XP_025111017.1 \\
\hline & Microtubule-actin cross-linking factor 1 -like isoform X5 & XP_025111018.1 \\
\hline & Microtubule-actin cross-linking factor 1 -like isoform X6 & XP_025111019.1 \\
\hline & Microtubule-actin cross-linking factor 1 -like isoform X7 & XP_025111020.1 \\
\hline & Microtubule-actin cross-linking factor 1-like isoform X8 & XP_025111021.1 \\
\hline & Microtubule-actin cross-linking factor 1 -like isoform X9 & XP_025111022.1 \\
\hline & Microtubule-actin cross-linking factor 1 -like isoform $\mathrm{X} 10$ & XP_025111023.1 \\
\hline & Microtubule-actin cross-linking factor 1 -like isoform X11 & XP_025111024.1 \\
\hline & Microtubule-actin cross-linking factor 1 -like isoform X12 & XP_025111025.1 \\
\hline & Hypothetical protein C0Q70_16043 & PVD22787.1 \\
\hline & Microtubule-actin cross-linking factor 1 -like isoform $\mathrm{X} 13$ & XP_025111026.1 \\
\hline & Hypothetical protein C0Q70_19248 & PVD21082.1 \\
\hline & Uncharacterized protein LOC112571766 & XP_025106825.1 \\
\hline
\end{tabular}

Table 3. KEGG analysis of the immune system pathways from the Limacus flavus body's transcriptome of Li et al., 2020.

\begin{tabular}{llr}
\multicolumn{1}{c}{ KEGG Pathway } & Pathway ID Gene Number \\
\hline Antigen processing and presentation & ko04612 & 128 \\
B cell receptor signaling pathway & ko04662 & 73 \\
Chemokine signaling pathway & ko04062 & 149 \\
Complement and coagulation cascades & ko04610 & 24 \\
Cytosolic DNA-sensing pathway & ko04623 & 42 \\
Fc epsilon RI signaling pathway & ko04664 & 71 \\
Fc gamma R-mediated phagocytosis & ko04666 & 120 \\
Hematopoietic cell lineage & ko04640 & 18 \\
Intestinal immune network for IgA production & ko04672 & 1 \\
Leukocyte transendothelial migration & ko04670 & 135 \\
NOD-like receptor signaling pathway & ko04621 & 60 \\
Natural killer cell mediated cytotoxicity & ko04650 & 69 \\
Platelet activation & ko04611 & 185 \\
RIG-I-like receptor signaling pathway & ko04622 & 37 \\
T cell receptor signaling pathway & ko04660 & 94 \\
Toll-like receptor signaling pathway & ko04620 & 68
\end{tabular}


bioRxiv preprint doi: https://doi.org/10.1101/2021.05.06.442857; this version posted June 28, 2021. The copyright holder for this preprint (which was not certified by peer review) is the author/funder, who has granted bioRxiv a license to display the preprint in perpetuity. It is made available under aCC-BY-NC-ND 4.0 International license.

Table 4. Aligments results of the fraction LFMP-Fp002 with ProteinBlast (blastp suite) from NCBI. Results with E value of 99, Total score of 33.9, Query cover of 100\% and restrict to Gastropoda (taxi: 6448), accessed in 11th December 2020.

\begin{tabular}{|c|c|c|c|c|c|}
\hline Common Name & Description & Accession & Common Name & Description & Accession \\
\hline \multirow{18}{*}{ Aplysia californica } & Uncharacterized protein LOC118477191 precursor & NP_001374013.1 & \multirow{5}{*}{ Lottia gigantea } & Hypothetical protein LOTGIDRAFT_154096 & XP_009060068.1 \\
\hline & Dynein heavy chain 5 , axonemal & XP_012940947.1 & & Hypothetical protein LOTGIDRAFT_154286 & XP_009060234.1 \\
\hline & Uncharacterized protein LOC106014199 isoform X1 & XP_035829882.1 & & Hypothetical protein LOTGIDRAFT_163508 & XP_009058267.1 \\
\hline & Uncharacterized protein LOC106014199 isoform X2 & XP_035829885.1 & & Hypothetical protein LOTGIDRAFT_233805 & XP_009058944.1 \\
\hline & Uncharacterized protein LOC106014199 isoform X3 & XP_035829886.1 & & Hypothetical protein LOTGIDRAFT_159926 & XP_009052863.1 \\
\hline & MAM and LDL-receptor class A domain-containing protein 1-like & XP_035827621.1 & \multirow{45}{*}{ Pomacea canaliculata } & Nesprin-1-like & XP_025097716.1 \\
\hline & ATP-binding cassette sub-family A member 7 & XP_035826205.1 & & Dystrophin-like isoform X1 & XP_025099291.1 \\
\hline & Uncharacterized protein LOC101846800 & XP_012935443.1 & & Dystrophin-like isoform X2 & XP_025099292.1 \\
\hline & Mediator of RNA polymerase II transcription subunit 24 isoform X1 & XP_035828357.1 & & Dystrophin-like isoform X4 & XP_025099294.1 \\
\hline & Mediator of RNA polymerase II transcription subunit 24 isoform X2 & XP_012943640.1 & & Dystrophin-like isoform X3 & XP_025099293.1 \\
\hline & Mediator of RNA polymerase II transcription subunit 24 isoform $\mathrm{X} 3$ & XP_035828361.1 & & Dystrophin-like isoform X5 & XP_025099295.1 \\
\hline & Mitogen-activated protein kinase kinase kinase 12 & XP_012941530.1 & & Dystrophin-like isoform X6 & XP_025099296.1 \\
\hline & Coiled-coil domain-containing protein 157 & XP_005112671.2 & & Dystrophin-like isoform X8 & XP_025099299.1 \\
\hline & Fatty acid synthase & XP_035825335.1 & & Dystrophin-like isoform X7 & XP_025099297.1 \\
\hline & Phosphofurin acidic cluster sorting protein 2 & XP_035824704.1 & & Dystrophin-like isoform X9 & XP_025099300.1 \\
\hline & Uncharacterized protein LOC101853655 & XP_012945022.1 & & Dystrophin-like isoform X10 & XP_025099301.1 \\
\hline & Protein DEFECTIVE IN EXINE FORMATION 1 & XP_005093156.1 & & Hypothetical protein C0Q70_10445 & PVD27870.1 \\
\hline & Protein tyrosine phosphatase domain-containing protein 1 & XP_012937402.1 & & Protein MLP1 homolog isoform X1 & XP_025081401.1 \\
\hline \multirow{17}{*}{ Biomphalaria glabrata } & Uncharacterized protein LOC106070898 isoform X1 & XP_013086335.1 & & Centromere protein F-like isoform X2 & XP_025081402.1 \\
\hline & Uncharacterized protein LOC106070898 isoform X2 & XP_013086338.1 & & Protein MLP1 homolog isoform X3 & XP_025081403.1 \\
\hline & Uncharacterized protein LOC106070898 isoform X3 & XP_013086340.1 & & Protein MLP1 homolog isoform X4 & XP_025081404.1 \\
\hline & FH1/FH2 domain-containing protein 3-like isoform X2 & XP_013088030.1 & & Protein MLP1 homolog isoform X5 & XP_025081405.1 \\
\hline & FH1/FH2 domain-containing protein 3-like isoform X4 & XP_013088032.1 & & Uncharacterized protein LOC112558998 isoform X1 & XP_025085578.1 \\
\hline & FH1/FH2 domain-containing protein 3-like isoform X1 & XP_013088029.1 & & Hypothetical protein C0070_05311 & PVD34049.1 \\
\hline & Mediator of RNA polymerase II transcription subunit 24-like isoform X1 & XP_013062166.1 & & Uncharacterized protein LOC112558998 isoform X2 & XP_025085583.1 \\
\hline & FH1/FH2 domain-containing protein 3-like isoform $X 3$ & XP_013088031.1 & & Uncharacterized protein LOC112558998 isoform X3 & XP_025085584.1 \\
\hline & Mediator of RNA polymerase II transcription subunit 24-like isoform X2 & XP_013062169.1 & & CD109 antigen-like & XP_025114650.1 \\
\hline & Mediator of RNA polymerase II transcription subunit 24-like isoform X3 & XP_013062170.1 & & Hypothetical protein C0Q70_19421 & PVD21250.1 \\
\hline & TPR repeat-containing protein DDB_G0287407-like & XP_013068676.1 & & Hypothetical protein C0Q70_20987 & PVD18438.1 \\
\hline & Uncharacterized protein LOC106050311 & XP_013060724.1 & & Hypothetical protein C0Q70_14895 & PVD24413.1 \\
\hline & Uncharacterized protein LOC106053133 & XP_013064058.1 & & Potassium channel subfamily T member 2-like isoform X1 & XP_025092878.1 \\
\hline & Uncharacterized protein LOC106068265 isoform X1 & XP_013083022.1 & & Potassium channel subfamily $\mathrm{T}$ member 2 -like isoform $\mathrm{X} 2$ & XP_025092879.1 \\
\hline & Uncharacterized protein LOC106068265 isoform X2 & XP_013083023.1 & & Potassium channel subfamily $T$ member 2 -like isoform $X 3$ & XP_025092880.1 \\
\hline & Uncharacterized protein LOC106068265 isoform X3 & XP_013083024.1 & & Hypothetical protein C0Q70_07182 & PVD31764.1 \\
\hline & Protein DEFECTIVE IN EXINE FORMATION 1-like & XP_013071770.1 & & Hypothetical protein C0Q70_10265 & PVD30989.1 \\
\hline \multirow{10}{*}{ Elysia chlorotica } & Hypothetical protein EGW08_008382 & RUS83841.1 & & Hypothetical protein C0Q70_06694 & PVD31282.1 \\
\hline & Hypothetical protein EGW08_020654 & RUS71593.1 & & Uncharacterized protein LOC112563014 & XP_025092477.1 \\
\hline & Hypothetical protein EGW08_005713 & RUS86521.1 & & Mitogen-activated protein kinase kinase kinase 13 -like & XP_025107273.1 \\
\hline & Hypothetical protein EGW08_019446 & RUS72786.1 & & Uncharacterized protein LOC112574226 & XP_025110915.1 \\
\hline & Hypothetical protein EGW08_004406 & RUS87807.1 & & Dystrobrevin beta-like isoform X1 & XP_025109383.1 \\
\hline & Hypothetical protein EGW08_002605 & RUS89587.1 & & Dystrobrevin beta-like isoform X2 & XP_025109384.1 \\
\hline & Hypothetical protein EGW08_004464 & RUS87799.1 & & Dystrobrevin beta-like isoform X3 & XP_025109386.1 \\
\hline & Hypothetical protein EGW08_005203 & RUS87050.1 & & Hypothetical protein C0Q70_10702 & PVD28120.1 \\
\hline & Hypothetical protein EGW08_023013 & RUS69223.1 & & Dystrobrevin beta-like isoform X4 & XP_025109387.1 \\
\hline & Hypothetical protein EGW08_018737 & RUS73497.1 & & Uncharacterized protein LOC112553775 & XP_025076998.1 \\
\hline \multirow{2}{*}{ Littorina littorea } & Toll-like receptor 30 & QNL15338.1 & & Protein tyrosine phosphatase domain-containing protein 1-like isoform X1 & XP_025106173.1 \\
\hline & Toll-like receptor 29 & QNL15337.1 & & Hypothetical protein C0Q70_14400 & PVD26722.1 \\
\hline \multirow{3}{*}{ Lottia gigantea } & Hypothetical protein LOTGIDRAFT_234295 & XP_009059810.1 & & Hypothetical protein C0Q70_19331 & PVD21164.1 \\
\hline & Hypothetical protein LOTGIDRAFT_129991 & XP_009063257.1 & & Uncharacterized protein LOC112570956 & XP_025105496.1 \\
\hline & Hypothetical protein LOTGIDRAFT_154099 & XP 009060070.1 & & Hypothetical protein C0Q70 16469 & PVD23206.1 \\
\hline
\end{tabular}


bioRxiv preprint doi: https://doi.org/10.1101/2021.05.06.442857; this version posted June 28, 2021. The copyright holder for this preprint (which was not certified by peer review) is the author/funder, who has granted bioRxiv a license to display the preprint in perpetuity. It is made available under aCC-BY-NC-ND 4.0 International license.

Table 5. Aligments results of the fraction LFMP-Fp003 with ProteinBlast (blastp suite) from NCBI.. Results with E value of 140, Total score of 18.0, Query cover of 100\% and restrict to Gastropoda (taxi: 6448), accessed in 11th December 2020.

Description
Uncharacterized protein LOC101864076
Uncharacterized protein LOC101845475
Uncharacterized protein LOC106064970 isoform X1
Uncharacterized protein LOC106064970 isoform X2
Uncharacterized protein LOC106064970 isoform X3
Uncharacterized protein LOC106064970 isoform X4
Uncharacterized protein LOC106064970 isoform X5
Uncharacterized protein LOC106064970 isoform X6
Uncharacterized protein LOC106064970 isoform X7
Uncharacterized protein LOC106064970 isoform X8
Uncharacterized protein LOC106064970 isoform X9
Uncharacterized protein LOC106064970 isoform X10
Uncharacterized protein LOC106064970 isoform X11
Uncharacterized protein LOC106064970 isoform X12
Chondroitin sulfate proteoglycan 4-like
Uncharacterized protein LOC106070666
Hypothetical protein LOTGIDRAFT_233112
Microtubule-actin cross-linking factor 1-like isoform X1
Microtubule-actin cross-linking factor 1-like isoform X2
Microtubule-actin cross-linking factor 1-like isoform X3
Microtubule-actin cross-linking factor 1-like isoform X14
Microtubule-actin cross-linking factor 1-like isoform X4
Microtubule-actin cross-linking factor 1-like isoform X5
Microtubule-actin cross-linking factor 1-like isoform X6
Microtubule-actin cross-linking factor 1-like isoform X7
Microtubule-actin cross-linking factor 1-like isoform X8
Microtubule-actin cross-linking factor 1-like isoform X9
Microtubule-actin cross-linking factor 1-like isoform X10
Microtubule-actin cross-linking factor 1-like isoform X11
Microtubule-actin cross-linking factor 1-like isoform X12
Hypothetical protein C0Q70_16043
Microtubule-actin cross-linking factor 1-like isoform X13
Hypothetical protein C0Q70_19248
Uncharacterized protein LOC112571766
Ud

\begin{tabular}{ll} 
Common Name & Accession \\
\hline Aplysia californica & XP_035826802.1 \\
Aplysia californica & XP_012939634.1 \\
Biomphalaria glabrata & XP_013079115.1 \\
Biomphalaria glabrata & XP_013079124.1 \\
Biomphalaria glabrata & XP_013079134.1 \\
Biomphalaria glabrata & XP_013079142.1 \\
Biomphalaria glabrata & XP_013079151.1 \\
Biomphalaria glabrata & XP_013079160.1 \\
Biomphalaria glabrata & XP_013079166.1 \\
Biomphalaria glabrata & XP_013079174.1 \\
Biomphalaria glabrata & XP_013079182.1 \\
Biomphalaria glabrata & XP_013079228.1 \\
Biomphalaria glabrata & XP_013079236.1 \\
Biomphalaria glabrata & XP_013079252.1 \\
Biomphalaria glabrata & XP_013095064.1 \\
Biomphalaria glabrata & XP_013086064.1 \\
Lottia gigantea & XP_009056900.1 \\
Pomacea canaliculata & XP_025111011.1 \\
Pomacea canaliculata & XP_025111012.1 \\
Pomacea canaliculata & XP_025111014.1 \\
Pomacea canaliculata & XP_025111027.1 \\
Pomacea canaliculata & XP_025111017.1 \\
Pomacea canaliculata & XP_025111018.1 \\
Pomacea canaliculata & XP_025111019.1 \\
Pomacea canaliculata & XP_025111020.1 \\
Pomacea canaliculata & XP_025111021.1 \\
Pomacea canaliculata & XP_025111022.1 \\
Pomacea canaliculata & XP_025111023.1 \\
Pomacea canaliculata & XP_025111024.1 \\
Pomacea canaliculata & XP_025111025.1 \\
Pomacea canaliculata & PVD22787.1 \\
Pomacea canaliculata & PVD21082.1 \\
&
\end{tabular}

